\title{
The Impact of Managers' Leadership Skills on Construction Project Performance in Dubai
}

\author{
Mr Hassan Asim Al Kazaz \\ Msc. Construction Cost and Project Management, Coventry University \\ Dr Abdussalam shibani \\ Lecture Construction and Project Management, Coventry University
}

\begin{abstract}
Dubai represents an icon in terms of development within the United Arab Emirates and Middle East in various fields; especially infrastructure, real estate, and tourism. The construction sector has witnessed a qualitative leap in terms of jobs requirements and type of production expected from people working in Dubai. Therefore, construction organisations are now looking for experienced professionals with effective leadership and management skills rather than technical experience; which is also important. Therapid development within the construction field has raised vast interest in the leadership aspect, and has encouraged organisations to seek effective methods to increase their chances of thriving within the Dubai market. The aim of this research is to investigate the impact of project managers' leadership skills on the construction project's performance in Dubai. A descriptive and an explorative mixed approach were used in this research to investigate practical experiences of professionals working within the industry. A questionnaire was conducted amongst employees of two reputed construction organisations to demonstrate their views in regards to leadership skills. A semistructured open-ended interview was also conducted with four senior project managers working for the Dubai construction field to identify the key elements of effective leaders and clarify the impact of leadership. The results revealed that leadership skills are a major factor that differentiates between effective leaders and managers. Moreover, any deficiency in technical skills can be recovered by developing effective leadership skills. Cultural awareness of any member working within the Dubai construction industry proposed to be a key factor in facilitating success. Also, effective leadership is highly attached to peoples' life and the quality of relations developed by the leader. In summary, there are different opinions about effective leadership and the convergence point among these opinions is people oriented and accommodated with the surrounding environment as a key factor for success.
\end{abstract}

\section{OVERVIEW}

Despite the large number of researches that have been written about leadership, still no general definition of leadership exists (Bass 2008), There is a large variety of definitions regarding leadership and the number of leadership definitions that exist are as many as the number of people who have tried to define it. Effective leadership is an essential element of any successful and effective management (Adair 2013). The leadership concept has been widely reviewed in different sectors, such as; business, education, health, military and others; however, there is a lack of research in the construction field in the Middle East. Leadership has been characterised through time in terms of qualities, behaviour, influence, interactional examples and additionally the role of relations. However, most meanings of leadership reflect the idea that it includes a procedure whereby one individual applies intentional impact over others to guide, structure, and encourage exercises and connections in a group of people or associations (Yukl 2013). In this research, leadership will be examined as: the capacities and skills of a person to influence, motivate, and empower others to contribute towards the adequacy and achievement of their organisation (Maxwell 2006). Moreover, it is noteworthy that leadership is essential in an attempt's success or failure. Modern arguments state that leadership is a key determinant of success or failure of a construction project; however, some arguments suggest that leadership is one minor factor amongst many that determines the success or failure of a project.

\section{AIM OF RESEARCH}

The aim of this research is to demonstrate the impact of managers' leadership skills within Dubai's construction sector, and how it can impact the overall performance of projects. 


\section{Project Management and Manager}

Construction Project Definition

A construction project is the production of a unique product by involving different specialities, such as: civil engineering, architectural and building engineering integrated in a serious of processes which lead to the completion of a project (Agyekum-Mensah 2012). Moreover, to understand the project management process, a brief definition of the project will be summarised as follows according to Kerzner (2009), who follows the PMBOK guide, as sequence of actvities and tasks:

- With a particular goal to be achieved according to approved specifications.

- With characterised, specific start and end dates.

- With specified financial limits.

- Consume human and non-human assets (i.e. cash, individuals, and equipment).

- With different specialties (Kerzner 2009).

\subsection{Project Management Process}

Project management is the process of applying knowledge, skills, tools, and technologies alongside the project activities to meet the project requirements. According to the PMBOK, the project management process includes five principle processes outlined below and represented in Figure 1.

- Initiating

- Planning

- Executing

- Monitoring and Controlling

- Closing

In order to manage a successful construction project, three main elements need to be identified and managed carefully. These are: the identification of project requirements, and addressing and satisfying the stakeholders' needs, concerns and expectations during the project planning and execution. Moreover, the third element is the balancing of project constraints, which are: scope, quality, schedule, budget, resources and risk. Thus, the project managers' focusing on these constraints will be influenced by the uniqueness of specific projects (PMBOK 2008). The benefits of applying project management techniques and procedures system will help to:

- Identify practical obligations to guarantee that all activities are represented.

- Minimise the requirement for consistent reporting.

- Clarify time limitations.

- Apply suitable strategies based on the trade-off analysis.

- Measure achievement against previous plans.

- Identify the problems earlier followed by correct actions.

- Develop future planning by advanced estimating possibilities.

- Clarify when objectives cannot be achievedto prevent exceeding them (Kerzner2009).

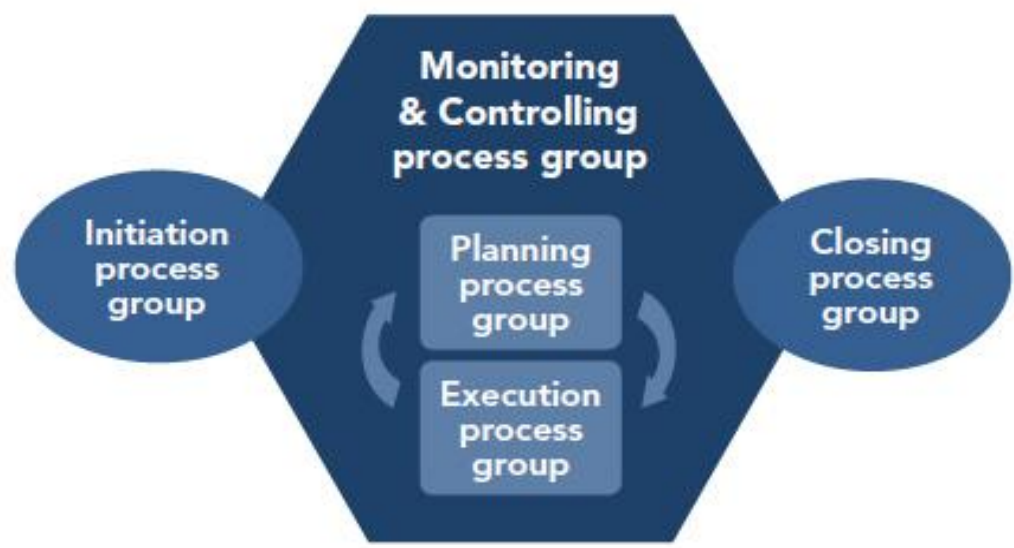

Figure1. Project Management Process, Source PMBOK (2008) 
However the benefits mentioned above are determined by certain factors that need to be overcome, which are; project complexity, customer's special requirements and scope changes, organizational restructuring, project risks, changes in technology, forward planning and pricing ( Kerzner 2009).

A broad definition of project management summarized from the above discussion is "to arrange, coordinate, and control the organization's assets for a generally transient target that has been established to finish particular objectives and targets.

\subsection{What is a Successful Project?}

The well known definition of a successful project is a project that is completed on time, within budget in accordance to an approved quality. Kerzner (2009) has maximised these three factors and developed a well defined description of a successful project, which is as follows:

- Completed within the specified time frame,

- Within the planned cost,

- Excecuted in the best possible way with suitable determination,

- User and customer are satisfied,

- Had minimal changes and deviations from the original plans,

- Did not constrain the fundamental work stream of the company,

- And does not affect the organisational culture of the company.

The last three components require further clarification. Only a few projects are completed in accordance to the original plans with no modifications made to the project. Scope changes are unavoidable and can possibly destroy the project morale, as well as the whole project. Scope changes can highly affect project performance, and changes should be kept to as minimal as possible, only changes that are essential should be approved and reviewed by the manager and the client ( Kerzner 2009).

Moreover, Sir John Egan has argued that construction project performance is a process based on accumulated database available for future projects;

"We see that construction has two choices: ignore all this in the belief that construction is so unique that there are no lessons to be learned; or seek improvement through re-engineering construction, learning as much as possible from those who have done it elsewhere"(Egan 1998)

Sir John Egan has explained in detail the construction industry has many issues and flaws that have been repeated; which relate to the fragmentation, these issues can be used to improve project performance by using previous information on problems faced by similar projects. This means that improvement does not only relate to the final product but can also used to review the process of construction management and create a database for future projects to refer to as a guide. Project success does not reflect the actual performance of the company or its management strategy. Project management success has many determinants and is defined as a series of continuous managed projects with a corporate responsibility to manage the project with dedication (PMBOK 2008).

\subsection{Project Manager Role}

The project manager's responsibility starts with defining the primary objectives of the project, which includes developing individual, team and general project objectives. Then, the project manager should correspond successfully with team members to acquire their commitment for accomplishing the objectives (CIOB 2002). These involve:

- Satisfying the client's objectives mentioned in the contract documents.

- Treating the project parties fairly.

- Focusing on the consumer/ customer.

- Ensuring the client is pleased.

The project manager is in charge of organising and incorporating activities over various practical lines. The integration process of activities includes the activities essential to develop a project plan, to 
execute the plan and finally to make changes to the plan (Kerzner 2009). These integrative obligations as mentioned in Figure 2 show that the project manager is responsible in transferring the inputs into outputs as productivity. The project manager could manage this process effectively if he or she has effective communication and interpersonal skills, knowledge about the operations that occur within the organisation and is up to date with the technologies that are used. However, project culture tends to mean that everything appears to rotate around the project manager.

In spite of this, the organisation is specialised and task-oriented; as some traditional attitudes are adopted (PMBOK2008). Hence, the project manager should reduce the gap between the parties by taking major responsibility for- namely relationship management or interface management:

- Amongst the project members,

- Between the project group and the utilitarian associations,

- Between the project group and senior management,

- Between the project group and the customer.

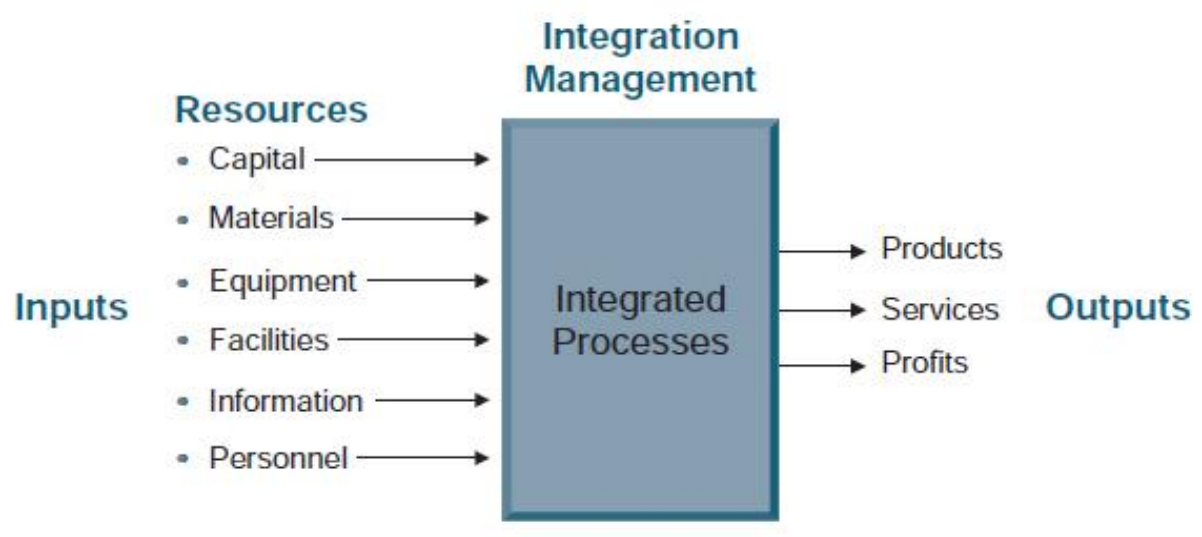

Figure2. Project Manager Role, Source Kerzner (2009)

Moreover, an effective project manager must have leadership skills as well as technical skills. Nevertheless, engineers in the construction sector must consider that their career may be limited in a specific speciality and they must also consider project management as different discipline that requires special capabilities. In summary, the project manager's role is a general role that copes with total operations of the organisation more than most of the executives. Therefore, project management principles are often used to prepare and train people who will occupy higher managerial positions in the future (PMBOK 2008).

\subsection{Major Differences between Managers and Leaders}

According to (Drucker 1999), the difference between leaders and managers is that leaders do the right things, however managers do things right. Moreover, in order to distinguish managers from leaders, we should consider leaders as managers who exercise management effectively ( Mintzberg 2009). On the other hand, Kubicek (2011) has stated that leaders are liberating while managers tend to dominate, effective leaders are those who use their position to liberate workers rather than dominate workers. Kotter (2001) argued that a manager's role is more about making sure that the company is following specific procedures and rules efficiently to celebrate continuous improvement, whereas leaders focus on providing inspiration and energy for their followers. Researchers have argued this issue and different opinions have resulted from this. For instance, the difference between leaders and managers still depends on the role within the organisation and culture, so it is not easy to summarise differences in one definition.

\subsection{Comparison between Management and Leadership}

'Leader' is the most favourable description for anyone occupying a managerial position because of the need to be suitable to fill the position that people are following. Nonetheless, when looking closely at the managerial leadership, it will be clear that "leadership" here includes the utilisation of formal power (i.e. controlling, facilitating and coordinating . Research has been conducted by proposing a diagnostic refinement in the middle of "headship" and 'leadership' (Rollinson 2002). 
These two terms distinguish two different types of leadership outcomes. "headship" aka the boss means that the manger use their position and the authority they have, however, leadership refers to open access authority which is inspired from the followers who supported the manager and helped the manager secure the position. "Headship" may take care of business, however it just secures consistence, not the eagerness and distinguishing proof of individuals with a procedure, which brings the highest level of execution.

Managerial 'headship' could be eliminating with decentralisation, distributing of authorities and support teams; bosses are turning to leaders by developing interpersonal skills, establishing an inspirational contact with their subordinates and using informal authority with their followers and sharing leadership that results from knowledge ,charisma and effective ideas(Rollinson 2002).

The differences and similarities between management and leadership are illustrated in Figure (3). Effective management must be reasonable, clarify any confusion, transform any unpredictable or eccentric plans into standards, take care of value-based connections, set fruitful examples of conduct and maintain viable working systems (Barker 1997). Management is concerned generally with 'doing'; it is moderately short term, task centred, is not a direct part of the team; instead it overlooks the team, provides structure and is a system used to support the inventive plans of the team.

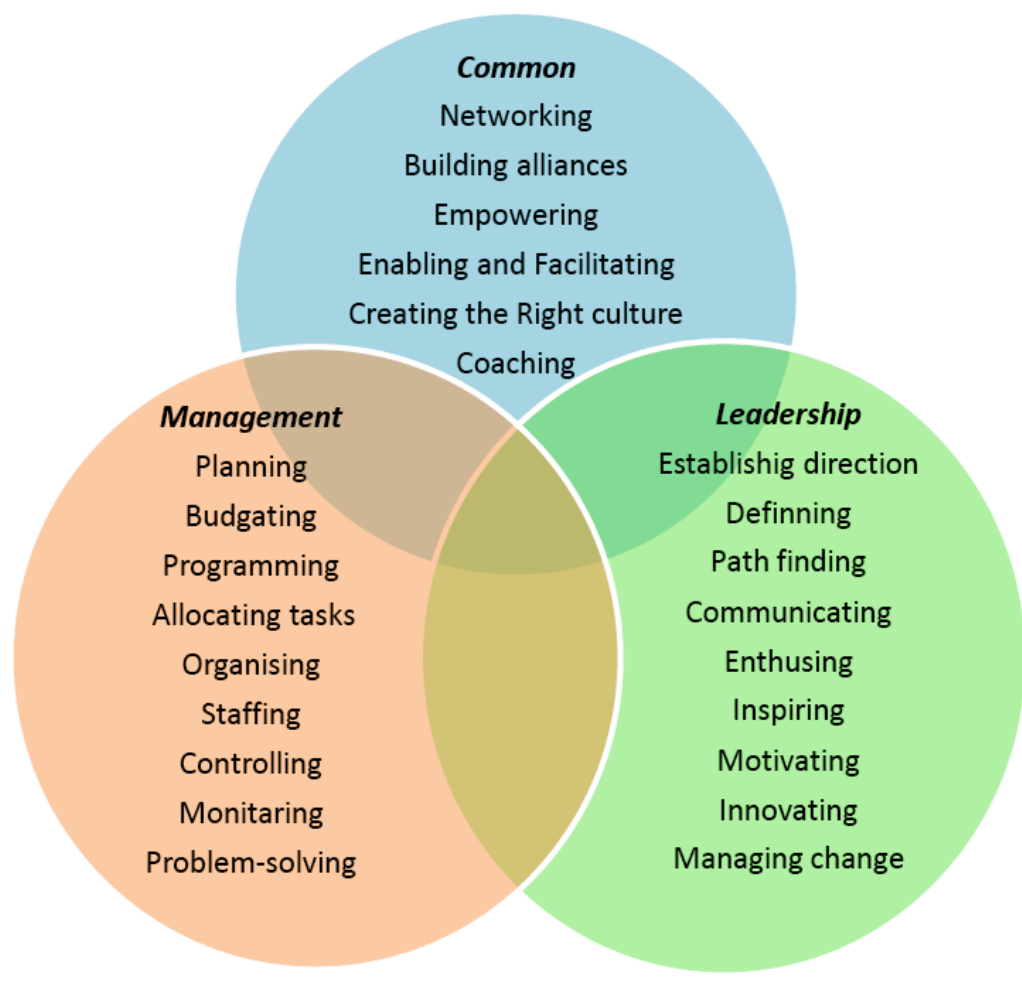

In comparison to management, leadership includes considering, visioning, moving, taking a more extended perspective, invigorating, building connections, systems management and giving advice in terms of vulnerability and change. Leadership has more access to the team, and aims to inspire, impact and influence the team. Leadership is more restricted that management, as it is more a mental contract in which the needs of the leaders and adherents are commonly fulfilled. This relationship is delicate and always shows signs of change. It cannot depend exclusively on formal power, or on authority given from above, solely on the individual aptitudes of the pioneers and the force. It is about impact, having the capacity to ingrain a feeling of mission and influence individuals to play their parts in making future requests (Sadler-Smith 2006).

\section{LEADERSHIP AND LEADERSHIP SKILLS}

\subsection{Leader Definition}

A leader is not the person who leads people, but the person that people will follow. Leaders are people who recognise what needs to be done and derive changes. They find new directions, adjust, inspire and motivate individuals, share the vision of the organisation and where is it heading and build effective teams. They also share decisions with the team, act as a mentor, train employees and delegate tasks appropriately to the right people (Skipper and Bell 2006). 


\subsection{Leadership Approach}

Previous studies demonstrated the impact of having no leadership in place, and the results showed that in order for a project to be successful, leadership has to be present. The majority of modern studies describe leadership as a fundamental skill. Dubai has been chosen in this study due to the variety of construction projects that are being constructed in this city. Some researchers believe that the financial, environmental, social and modern conditions have a much more prominent effect on the organisational achievement than the role of managers (Nahavandi 2003). Also previous studies have focused on the study of leadership styles, however, there is still little information regarding the effect of leadership skills on project performance and success.

\subsection{Leadership Theories}

There are five major theories of leadership style and quality, they are; contingency, transformational, value-based, circulated and structuralised (Munshiet al. 2005). Most previous research have focused on the styles and traits of leadership. Many critics have argued however that these characteristics are not essential in order for a person to become a leader; they are desirable (Wright 1996). Moreover, leadership cannot be defined by as an individual leader and the concept of leadership is wider than the leader (Fairholm 2004). Subsequently, the contingency approach describes leadership actions, as a situational reaction to a particular action. This approach has been argued and criticized by some researchers, for example, Grint (2005) argues that the leader's actions are determined in accordance to the situation they find themselves in and the previous choices they made. On the other hand, the third approach- the transformational and transactional approach- depends on the culture and power relations that run alongside the leadership research. These two approaches relate to the similarities between leaders and followers(Winkler 2010). The previously mentioned leadership styles take into account the kind of treatment given to followers (e.g. reward and punishment), which can affect the behaviour and attitude of followers, and leadership skills and attitude could be transferred as charismatic attributes through effective communications (Mumford and strange 2002). However, Wright (1996) argued that transformational leadership is not applicable due to the differences in the individual's personality and style. The reason for investigating various leadership traits in this research is because there is a relationship between leadership skills and leadership traits. This means that with the correct leadership skills, the overall performance of managers can be enhanced if managers have the correct attitude and characteristics.

\subsection{The Character of a Leader}

This is a basic approach that was mentioned in earlier studies regarding leadership. This approach underscores leaders' traits, for example, identity, intentions, qualities and abilities. The basic concept of this approach is that leaders are born and not created which means that some people have exceptional abilities and qualities that qualify them to lead and that is not acquired from others(Yukl 2013). In addition, the difference between exceptional leaders and normal leaders is the inherited traits(French et al. 2011). Nonetheless, the alleged extraordinary man theories of the mid 1900s neglected to confront exploratory tests, in other words, they failed to highlight the qualities that are vital and adequate for management success (Jackson 1995). The reason why it was so hard to speculate the characteristics of a leader is because it is very difficult to collect and find the exact attributes that contribute to becoming a leader. However, the inherited leadership concept that leaders are born and not created is not accepted in most of modern research as it shows limited views of understanding leadership across cultures. Recent research demonstrates that skills connected with an effective leader are not general traits (French, 2007). On the other hand, the term initiative suggests that the individual possesses such a part to complete their leadership duties (French et al. 2011).

\subsection{Leadership Models}

During the research process, the author found ten leadership models that explored leadership from different perspectives, these models will be reviewed in this section. Three of the models combined the leader's personality, attribute, capability and team building skills. These three models are as follows:

- Mintzberg's model of leadership and Management.

- Lencioni's model of five Dysfunctions of a Team. 
- Leadership -exchanging between Leader and member

Methodology

\section{Purpose of ReSearch}

The main reasons for conducting research can be categorised into 4 main categories, they are; descriptive, explorative, diagnostic and experimental (Kumar 2014). However, Yin(2013) summrised research and categorized them into three main categories, they are; descriptive, exploratory and experimental. Descriptive refers to the development and explanation of empirical speculations (Yin 2013). This type of research incorporates an integrated description of a sensation with its context based on existing hypotheses and theories (Saunders,Lewis and Thornhill 2009). The second category, explorative research is suitable for problems that are hard to limit and focus on and the amount of previous research conducted is not sufficient (Yin 2013). The third category of research is experimental; this type of research identifies the causative relationships between cause and effect (Yin 2013). In addition, this research is ideal for proving or disapproving specific connections with particular characteristics.

As mentioned previously the purpose and aim of the research is to investigate the impact of leadership skills of managers within the Dubai construction industry. Due to the lack of research in this subject, and to reach a deeper understanding of the research aims, the management process and project manager roles are described. Leadership theories and modules were addressed in the previous chapter to support the need for research. Subsequently, leadership skills are investigated and summarised based on the models and previous literature. An initial list of skills required for a leader based on previous studies was created and was used as a guide for research methodology and data collection. Therefore, it can be said that this research is descriptive; however, it can also be exploratory as it is conducted in a new field of study or industry.

\section{RESEARCH APPROACH}

\subsection{Qualitative Versus Quantitative Approaches}

Describing the quantitative approach with numbers and the qualitative approach with words is not is not quite as simple as expected (Eliot 2010). Whilst a qualitative research is more about understanding complicated relationships, quantitative research concerns the explanation and control of certain factors. Moreover, qualitative research also entails investigating factors to see if one factor occurs more or less than another during a time period, qualitative research often requires no explanation whilst quantitative research takes in depths look at the cause and effect of a factor (Creswell 2014). Qualitative approach is based on subjective judgement, synthesizing and analysing data constantly, whereas, a quantitative approach interprets the whole data obtained uses statistics for analysis (Eliot 2010).Qualitative research enquiries are intended to search for unanticipated connections in addition to the expected arrangement of variables. Quantitative research inspects connections amongst a small number of foreordained variables; uniqueness is also set up through the "gathering of elements and succession of happenings basic to comprehension a specific circumstance." Alternatively, uniqueness in quantitative research occurs by comparing variables against each other (Eliot 2010).

\subsection{Mixed Approach}

This approach combines both qualitative and quantitative approaches (Creswell 2014). Early evaluations of the mixed approach showed that all approaches when used individually had weaknesses and were biased, therefore when combined together the weaknesses in data are eliminated. An example of qualitative data is open-ended questions without foreordained response; however, a quantitative approach is based on close-ended responses; such as questionnaires (Tashakkori andTeddlie2010). Tashakkori and Teddlie (2010) stated major advantages of using a mixed method, for instance, by integrating the qualitative and quantitative approaches together a database is established that can be used as a reference for other databases. Creswell and Plano Clark (2011) define the mixed approach as "a research design with philosophical assumptions as well as methods of inquiry". interviews with 10 different managers of reputable construction organisations in Dubai. 
Table1. Research Strategy Plan, Source Yin (2013)

\begin{tabular}{|c|c|c|c|}
\hline Strategy & $\begin{array}{c}\text { From research } \\
\text { question }\end{array}$ & $\begin{array}{c}\text { Requires control } \\
\text { over behavioural } \\
\text { events? }\end{array}$ & $\begin{array}{c}\text { Focuses on } \\
\text { contemporary } \\
\text { events? }\end{array}$ \\
\hline Experiment & How, Why & Yes & Yes \\
\hline Survey & $\begin{array}{l}\text { Who, What, } \\
\text { Where, How } \\
\text { many, How } \\
\text { much }\end{array}$ & No & Yes \\
\hline Archival analysis & How, why & No & Yes/ No \\
\hline history & How, why & No & No \\
\hline Case study & How, why & No & Yes \\
\hline
\end{tabular}

\section{Data Collection Procedure}

\subsection{Designing the Questionnaire}

By adopting a pragmatic approach to the research method, one of the main questions that can be answered using a quantitative approach is to test and check hypotheses (Muijs 2011). Appendix A shows the questionnaire, as can be seen it has been designed based on the research questions. The questionnaire is the first step in achieving the aims and objectives of the research. The questionnaires were aimed at employees working inside the head office of two specialised construction companies in Dubai. One of these was a consultancy firm and the other was a contractors firm. The reason behind choosing office employees was due to the fact that people who work in offices are more attached to the management process and their knowledge of daily conflicts, decision making and delegations are essential for collecting qualitative data about leadership skills. Also, office employees are more affected by leadership attitudes and styles. Moreover, the questionnaire mainly focused on identifying the most important leadership skills that could build an effective leader. However, it was designed to be flexible in order to receive comments from the respondents.

The questionnaire was divided into four sections:

- Demographic Information,

- Perspective of Project Success,

- Leadership Skills,

- Employee's Perception of Leadership.

\subsubsection{Demographic Information}

This section of the questionnaire contains basic information about the respondents. Questions in this part were stated as multiple choice questions, so the employees would not waste time filling the information in. However, this section did not contain any personal information in order to ensure the privacy of the employees. Collecting this information allowed me to discover some general information about the people working in the construction industry, such as: age, nationality, education and previous experience

\subsubsection{Perspective of Project Success}

The second section of the questionnaire asked participants about the success of construction projects in Dubai and included an evaluation from the employee's point of view. As mentioned earlier in the study, according to Kerzner (2009), a successful project has seven characteristics. Previous research regarding the success of construction project in Dubai's industries did not satisfy the research requirements, hence further investigation was conducted to discover what leadership skills are needed. Consequently, this questionnaire was designed to investigate major issues and uses summarised questions about project success to include an in-depth look at project success. This section started 
with a list of fifteen factors that could affect the project performance and could distinguish between a successful and failed project. The respondents were asked to rank these factors according to their experience and the organisational culture that they work in. These factors scaled from one to five: 1 meaning not important, 2 is low importance, 3 is of medium importance, 4 equalshigh importance, and finally, 5 is of extremely important.

\subsubsection{Leadership Skills}

The next section of the questionnaire looked at leadership skills and its impact on organisational success. As mentioned above, this questionnaire was distributed to people who work in the headquarters of the various companies because these employees are more likely to be influenced by the leadership aspects. They also have more experience and knowledge regarding leadership skills. This third section listed twenty leadership skills that were obtained from the literature study, and the respondents were asked to rank each leadership skill according to their experience. The effectiveness of leadership skills were presented on a scale of one to five: (1) rarely effective, (2) meaning occasionally effective, (3) is moderately effective, (4) being noticeably effective and finally, (5) meaning highly effective. In addition, respondents were provided with additional space to mention any other leadership skills that could be effective from their perspective as professionals.

Table2. Interview Questions

\begin{tabular}{|c|c|c|}
\hline \multicolumn{3}{|c|}{ The Interview Planed Subsections and Questions } \\
\hline SQ. & Subsections & Questions \\
\hline 1 & Personal information. & $\begin{array}{l}\text { 1) How many years have you worked in Dubai? } \\
\text { 2) How many organisations have you worked in before? } \\
\text { 3) Could you briefly explain your role in the organisation? }\end{array}$ \\
\hline 2 & $\begin{array}{l}\text { Leadership from a personal } \\
\text { perspective. }\end{array}$ & $\begin{array}{l}\text { 4) What is leadership from your perspective? } \\
\text { 5) How would you describe yourself as a leader in a few words } \\
\text { 6) What motivates you as a leader? } \\
\text { 7) Could you evaluate leadership in Dubai construction } \\
\text { environment? }\end{array}$ \\
\hline 3 & $\begin{array}{l}\text { interviewee's perception of } \\
\text { the core leadership skills } \\
\text { required for a career as a } \\
\text { project manager }\end{array}$ & 8) How do you manage conflicts amongst team members? \\
\hline 4 & $\begin{array}{l}\text { Definition of a successful } \\
\text { project }\end{array}$ & $\begin{array}{l}\text { 9) How would you describe a successful construction project? } \\
\text { D Could you please give an example? } \\
\text { 10) Have you managed an unsuccessful project? } \\
\text { Could you please give an example? }\end{array}$ \\
\hline 5 & $\begin{array}{l}\text { The impact of leadership } \\
\text { skills on project success }\end{array}$ & $\begin{array}{l}\text { 11) Could you summarise the impact of leadership skills on } \\
\text { project success? } \\
\text { 12) Did your organisation improve your leadership skills? } \\
\text { 13) Have you received any training before? } \\
\text { 14) Could you name the most important leadership skills that } \\
\text { distinguish between a successful and a standard leader? }\end{array}$ \\
\hline 6 & $\begin{array}{l}\text { Personal experiences } \\
\text { successful leadership and } \\
\text { competences } \text { associated with } \\
\text { this }\end{array}$ & $\begin{array}{l}\text { 15) Could you state a personal task about success in leadership } \\
\text { positions in Dubai's construction sector? }\end{array}$ \\
\hline
\end{tabular}

\subsubsection{Analysis}

The final element of the interviewing process is analysis or data interpretation. At this stage, the interviewer has to make sense of what was covered in the interview sessions and summarize the participant's ideas in a way that serves the research problem best (Creswell 2014). Moreover, three elements were used to analyse the data; the purpose of the study, the topic for investigation (Kvale 1996). Kvale (1996) developed a six staged approach for analysing an interview; they are; subject portrayal, subject disclosure, interpretation during interviewing, translation of transcripts, reinterviewing, and action. These steps have been summarised for the purpose of this research. The first step is to interpret the respondent's words, next comes the analysis and in-depth review of what the respondent stated; new findings are found here. The third stage is summarising the meaning and thoughts and the final step is to transcript. Kvale (1996) had described transcription as the final step to clarify and develop all meanings and bring the interviewee's own opinions into light and provide their viewpoints on the research subject (kvale 2007). 
By applying Kvale's data analysis approach, an in-depth analysis of the key leadership skills was conducted from different viewpoints. Recording the interviews has enabled the research to explore further topics around the research. The results and analysis are presented in the next chapter.

\section{ANALYSis AND ReSUlts}

\subsection{Reliability and Validity of the Questionnaires}

Validity is the capability to test and measure specific components that the test was designed for (Gregory 1992). Moreover, validity concerns how accurate the instrument used for testing is rather than the data itself, it ensures that the instrument used is appropriate for testing the components (Gregory 1992). In this research, questionnaires for the pilot study were given to the same companies chosen for the actual questionnaire. Respondents who participated in the pilot study had positive views on the content and the samples were approved as being suitable to address the research problem.

Reliability has been defined as "the degree to which one can expect relatively constant deviation scores of individuals across testing situations on the same, or parallel, testing instruments" (Fairchild 2003). In this research, the SPSS reliability test (Cronbach's Alpha) was used and the minimum reliability co-efficient was set to 0.70 in order to ensure the research is reliable. The reliability coefficient for the consultancy firm was 0.843 , which is an acceptable value. The reliability co-efficient for the contracting firm was 0.812 which is also acceptable, both values are higher than the minimum ratio of 0.7 . Figure (14) shows the ratios for this research.

Scale: Consultancy Company Cronbach's Alpha Reliability Test

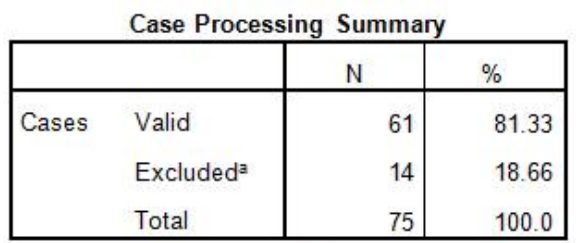

a. Listwise deletion based on all variables in the procedure.

Reliability Statistics

\begin{tabular}{|r|r|}
\hline $\begin{array}{c}\text { Cronbach's } \\
\text { Alpha }\end{array}$ & N of Items \\
\hline .843 & 55 \\
\hline
\end{tabular}

Scale: Contracting Company Cronbach's Alpha Reliability Test

\begin{tabular}{|c|c|c|c|}
\hline & & $\mathrm{N}$ & $\%$ \\
\hline \multirow[t]{3}{*}{ Cases } & Valid & 51 & 68.0 \\
\hline & Excluded $^{a}$ & 24 & 32.0 \\
\hline & Total & 75 & 100.0 \\
\hline
\end{tabular}

a. Listwise deletion based on all variables in the

procedure.

Reliability Statistics

\begin{tabular}{|r|r|}
\hline $\begin{array}{l}\text { Cronbach's } \\
\text { Alpha }\end{array}$ & N of Items \\
\hline & 55 \\
\hline
\end{tabular}

Figure14. Cronbach's Alpha Realiability Test 


\subsection{Analysis}

\subsubsection{Demographic Data and General Characteristics}

Section one of the survey asked respondent's general information about the nationality, gender, age, marital status, number of previous employers and years of experience they have working within the industry. Table 4 below presents the demographic information obtained from the survey. Firstly, the nationality of the majority of participants were Indian; more than half of office employees were Indian, 23.21\% were East Asian, and 16.07\% were Arabs.

It was also found that the majority of participants were males; the questionnaire was male-dominated with $90 \%$ of participants being men. The age of employee's varied, the range was between 21-55, and the majority were aged 26-30.

Moreover, results show that most of office employees are graduated and 36\% of participants had obtained the company they work in as their first employer; this gives a positive impression about the organisational culture.

Table4. Demographic Information Obtained from the Questionnaires

\begin{tabular}{|c|c|c|c|}
\hline \multicolumn{2}{|c|}{ Information } & Frequency & Percentage \\
\hline \multirow[t]{7}{*}{ Nationality } & UAE national & 2 & $1.79 \%$ \\
\hline & Arab national & 18 & $16.07 \%$ \\
\hline & Indian & 57 & $50.89 \%$ \\
\hline & European & 7 & $6.10 \%$ \\
\hline & East Asian & 26 & $23.21 \%$ \\
\hline & Canadian & 2 & $1.79 \%$ \\
\hline & Other & $\mathbf{0}$ & $0.00 \%$ \\
\hline \multirow[t]{2}{*}{ Gender } & Male & 101 & $90.18 \%$ \\
\hline & Female & 11 & $9.82 \%$ \\
\hline \multirow[t]{6}{*}{ Age } & $21-25$ & 10 & $8.93 \%$ \\
\hline & $26-30$ & 44 & $39.29 \%$ \\
\hline & 31-35 & 29 & $25.89 \%$ \\
\hline & $36-45$ & 24 & $21.43 \%$ \\
\hline & $46-55$ & 3 & $2.68 \%$ \\
\hline & Above 55 & 2 & $1.79 \%$ \\
\hline \multirow[t]{3}{*}{ Marital Status } & Single & 33 & $29.46 \%$ \\
\hline & Married & 77 & $68.75 \%$ \\
\hline & Divorced & 2 & $1.79 \%$ \\
\hline \multirow[t]{5}{*}{ Education } & High School & $\mathbf{0}$ & $0.00 \%$ \\
\hline & Diploma & 26 & $23.21 \%$ \\
\hline & BSC & 72 & $64.29 \%$ \\
\hline & MSC & 12 & $10.71 \%$ \\
\hline & PHD & 2 & $1.79 \%$ \\
\hline
\end{tabular}

\begin{tabular}{|c|c|c|c|}
\hline \multicolumn{2}{|c|}{ Information } & Frequency & Percentage \\
\hline \multirow[t]{7}{*}{ Experience (Years) } & 0 to 3 & 17 & $15.18 \%$ \\
\hline & 4 to 5 & 25 & $22.32 \%$ \\
\hline & 6 to 10 & 33 & $29.46 \%$ \\
\hline & 10 to 15 & 28 & $25.00 \%$ \\
\hline & 16 to 20 & 5 & $4.46 \%$ \\
\hline & 20 to 30 & 3 & $2.68 \%$ \\
\hline & Above 30 & 1 & $\mathbf{0 . 8 9 \%}$ \\
\hline \multirow[t]{8}{*}{ Previous employers } & 1 & 41 & $36.61 \%$ \\
\hline & 2 & 21 & $18.75 \%$ \\
\hline & 3 & 27 & $24.11 \%$ \\
\hline & 4 & 11 & $9.82 \%$ \\
\hline & 5 & 10 & $8.93 \%$ \\
\hline & 6 to 8 & 2 & $1.79 \%$ \\
\hline & 8 to 10 & $\mathbf{0}$ & $0.00 \%$ \\
\hline & Above 10 & $\mathbf{0}$ & $0.00 \%$ \\
\hline
\end{tabular}




\subsubsection{Perspective of Project Success}

Section two of the questionnaire asked participants to rank 50 project success factors that were obtained from the literature study. Participants had to rank each factor using a scale of 1 to 5 based on what they think is the least and most important success factors. Figure (15) and table (5) present the most important factors from an employee's perspective. According to the mean analysis, the three most important factors were; motivating team members; $50 \%$ of respondents agreed that this is the most important factor, the second most important factor was effective leadership being one of the main factors to affect project success, the third most important factor was found to be reducing changes and the scope of the project.

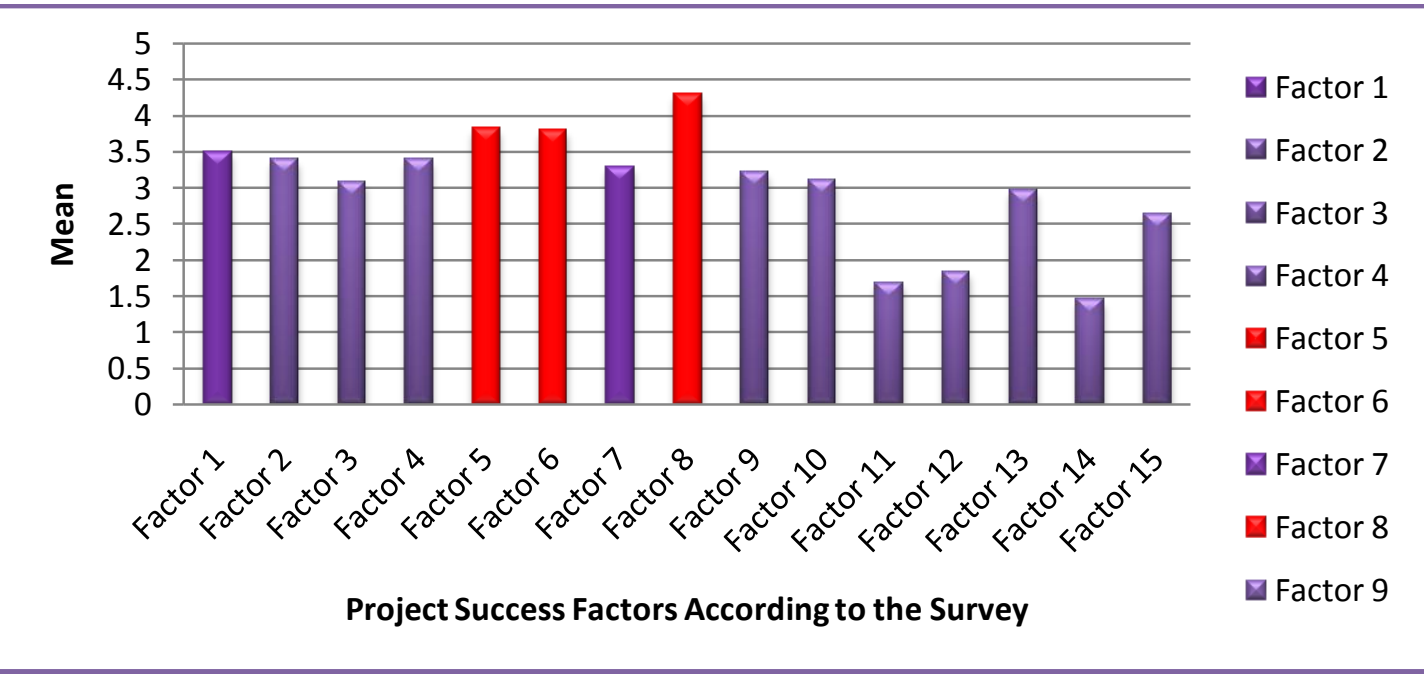

Figure15. Least and Most Important Success Factors

Table5. Project Success Factors ranked

\begin{tabular}{|c|c|c|c|c|c|c|c|c|c|c|c|c|}
\hline \multirow[t]{2}{*}{ SQ. } & \multirow[t]{2}{*}{ Project Success Factors } & \multicolumn{2}{|c|}{\begin{tabular}{|l} 
Not \\
Important= 1
\end{tabular}} & \multicolumn{2}{|c|}{$\begin{array}{l}\text { Low } \\
\text { Importance }=2\end{array}$} & \multicolumn{2}{|c|}{\begin{tabular}{|l} 
Medium \\
Importance= 3
\end{tabular}} & \multicolumn{2}{|c|}{\begin{tabular}{|l|} 
Very \\
Important $=4$
\end{tabular}} & \multicolumn{2}{|c|}{\begin{tabular}{|l} 
Extremely \\
Important= 5
\end{tabular}} & \multirow[t]{2}{*}{ Mean } \\
\hline & & $F$ & $\%$ & $\boldsymbol{F}$ & $\%$ & $\boldsymbol{F}$ & $\%$ & $F$ & $\%$ & $\boldsymbol{F}$ & $\%$ & \\
\hline 1 & Clarity of project goals & 8 & $7.14 \%$ & 13 & $11.61 \%$ & 32 & $28.57 \%$ & 33 & $29.46 \%$ & 26 & $23.21 \%$ & 3.50 \\
\hline 2 & Effective leadership & 1 & $.89 \%$ & 3 & $2.68 \%$ & 34 & $30.35 \%$ & 51 & $\mathbf{4 5 . 5 3 \%}$ & 23 & $20.53 \%$ & 3.82 \\
\hline 3 & $\begin{array}{l}\text { Leadership skills of } \\
\text { project manager }\end{array}$ & 2 & $1.78 \%$ & 39 & $34.82 \%$ & 26 & $23.21 \%$ & 38 & $33.92 \%$ & 7 & $6.25 \%$ & 3.08 \\
\hline 4 & $\begin{array}{l}\text { Technical skills of } \\
\text { project manager }\end{array}$ & 4 & $22.32 \%$ & 16 & $14.29 \%$ & 36 & $31.25 \%$ & 44 & $21.43 \%$ & 12 & $10.71 \%$ & 3.39 \\
\hline 5 & $\begin{array}{l}\text { Being an effective } \\
\text { leader }\end{array}$ & 1 & $0.89 \%$ & 24 & $21.42 \%$ & 35 & $31.25 \%$ & 34 & $30.35 \%$ & 18 & $16.07 \%$ & 3.39 \\
\hline 6 & \begin{tabular}{|l|} 
Reducing project \\
Scope changes
\end{tabular} & 1 & $7.14 \%$ & 12 & $10.71 \%$ & 10 & $8.93 \%$ & 42 & $37.50 \%$ & 39 & $34.82 \%$ & 3.79 \\
\hline 7 & $\begin{array}{l}\text { Qualification of } \\
\text { project team members }\end{array}$ & 13 & $11.61 \%$ & 14 & $12.50 \%$ & 32 & $28.57 \%$ & 34 & $30.36 \%$ & 19 & $16.96 \%$ & 3.29 \\
\hline 8 & $\begin{array}{l}\text { Motivation of project } \\
\text { team members }\end{array}$ & 2 & $1.79 \%$ & 4 & $3.57 \%$ & 9 & $8.04 \%$ & 41 & $36.60 \%$ & 56 & $50.0 \%$ & 4.29 \\
\hline 9 & \begin{tabular}{|l|} 
Effective \\
communication \\
between project \\
stakeholders \\
\end{tabular} & 6 & $5.35 \%$ & 22 & $19.64 \%$ & 34 & $30.36 \%$ & 41 & $36.60 \%$ & 9 & $8.04 \%$ & 3.22 \\
\hline 10 & $\begin{array}{l}\text { Effective coordination } \\
\text { of project activities }\end{array}$ & 4 & $3.57 \%$ & 36 & $32.14 \%$ & 26 & $23.21 \%$ & 35 & $31.25 \%$ & 11 & $9.82 \%$ & 3.11 \\
\hline 11 & $\begin{array}{l}\text { Systematic control } \\
\text { over the execution of } \\
\text { the project }\end{array}$ & 44 & $39.29 \%$ & 26 & $23.21 \%$ & 18 & $16.07 \%$ & 6 & $5.36 \%$ & 3 & $2.68 \%$ & 1.69 \\
\hline 12 & \begin{tabular}{|l|} 
Access to \\
organizational \\
resources
\end{tabular} & 65 & $58.04 \%$ & 14 & $12.50 \%$ & 24 & $21.43 \%$ & 4 & $3.57 \%$ & 5 & $4.46 \%$ & 1.84 \\
\hline 13 & SMART planning & 16 & $14.29 \%$ & 32 & $24.11 \%$ & 21 & $18.75 \%$ & 25 & $22.32 \%$ & 18 & $20.54 \%$ & 2.97 \\
\hline 14 & \begin{tabular}{|l|}
$\begin{array}{l}\text { Competence of project } \\
\text { consultant }\end{array}$ \\
\end{tabular} & 87 & $77.68 \%$ & 13 & $11.61 \%$ & 3 & $2.68 \%$ & 5 & $4.46 \%$ & 4 & $3.57 \%$ & 1.45 \\
\hline 15 & $\begin{array}{l}\text { Top management } \\
\text { support }\end{array}$ & 22 & $19.64 \%$ & 34 & $30.36 \%$ & 32 & $28.57 \%$ & 11 & $9.82 \%$ & 13 & $11.61 \%$ & 2.63 \\
\hline
\end{tabular}




\subsubsection{Leadership Skills}

Section 3 of the questionnaire asked participants to rank twenty leadership skills obtained from the literature study. Participants had to rank each factor using a scale of 1 to 5 based on what they think is the least and most important leadership skills. Figure (16) and Table (6) present the most important skills from an employee's perspective. The top five leadership skills were found to be; first was motivational skills, second was knowledge, third was planning skills, fourth was decision making skills and fifth was communication. A team working skill almost made the top 5 and is found to be effective and will be included in the discussion.

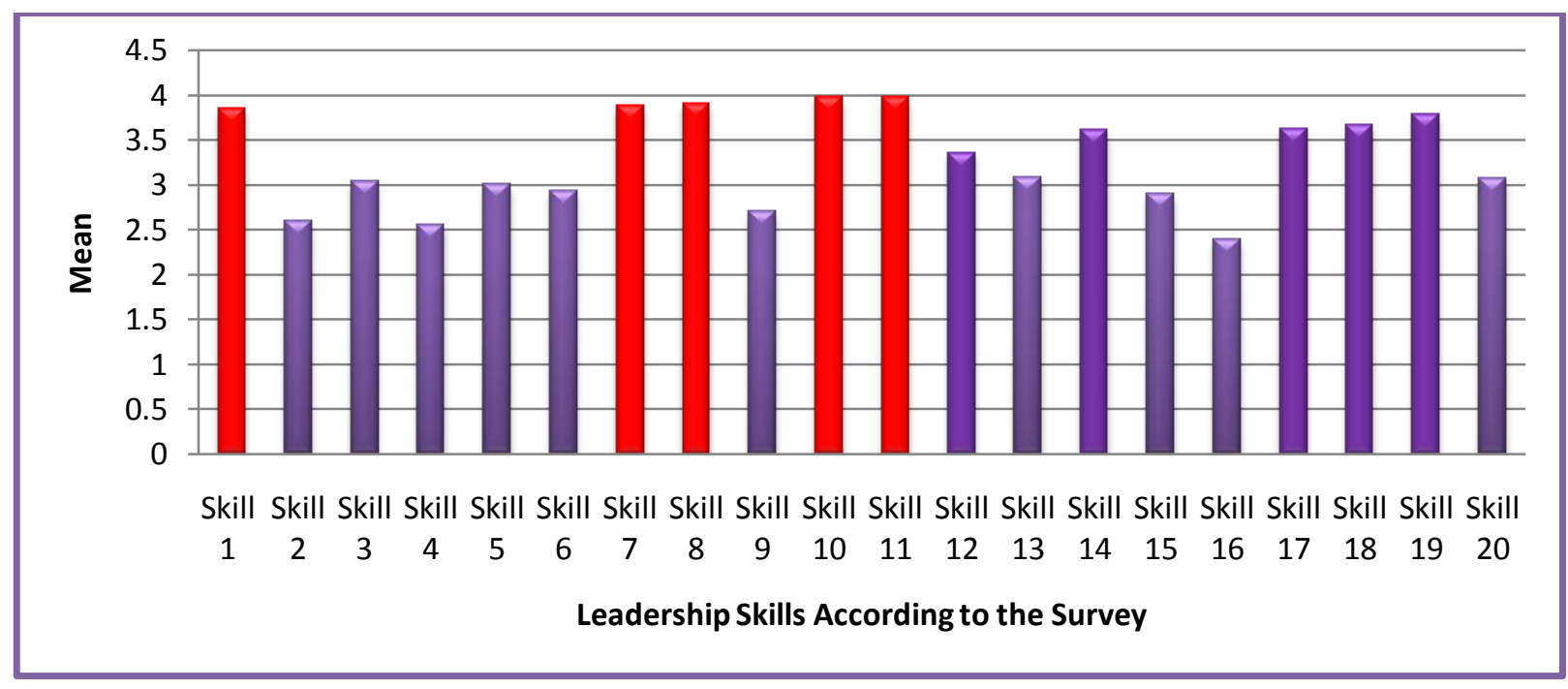

Figure16. Least and most important Leadership Skills

Table6. Leadership Skills Results Ranked

\begin{tabular}{|c|c|c|c|c|c|c|c|c|c|c|c|c|}
\hline \multirow[t]{2}{*}{ SQ } & \multirow[t]{2}{*}{ leadership Skills } & \multicolumn{2}{|c|}{$\begin{array}{l}\text { Rarely } \\
\text { effective }=1\end{array}$} & \multicolumn{2}{|c|}{$\begin{array}{l}\text { Occasionally } \\
\text { effective }=2\end{array}$} & \multicolumn{2}{|c|}{$\begin{array}{l}\text { Moderately } \\
\text { effective }=3\end{array}$} & \multicolumn{2}{|c|}{$\begin{array}{l}\text { Noticeably } \\
\text { effective }=4\end{array}$} & \multicolumn{2}{|c|}{$\begin{array}{l}\text { Highly } \\
\text { effective }=5\end{array}$} & \multirow[t]{2}{*}{ Mean } \\
\hline & & $\boldsymbol{F}$ & $\%$ & $\boldsymbol{F}$ & $\%$ & $F$ & $\%$ & $F$ & $\%$ & $\boldsymbol{F}$ & $\%$ & \\
\hline 1 & Communication Skills & 3 & $2.68 \%$ & 22 & $19.64 \%$ & 14 & $12.50 \%$ & 22 & $19.64 \%$ & 51 & $45.53 \%$ & 3.85 \\
\hline 2 & Interpersonal Skills & 2 & $1.79 \%$ & 39 & $34.82 \%$ & 33 & $29.46 \%$ & 24 & $21.43 \%$ & 14 & $12.50 \%$ & 3.08 \\
\hline 3 & Managing Conflict & 2 & $1.79 \%$ & 17 & $15.18 \%$ & 38 & $33.93 \%$ & 40 & $35.71 \%$ & 15 & $13.39 \%$ & 3.44 \\
\hline 4 & Mentoring Skills & 8 & $7.14 \%$ & 39 & $34.82 \%$ & 44 & $39.29 \%$ & 14 & $12.50 \%$ & 7 & $6.25 \%$ & 2.76 \\
\hline 5 & $\begin{array}{l}\text { Controlling group } \\
\text { performance }\end{array}$ & 7 & $6.25 \%$ & 31 & $27.68 \%$ & 37 & $33.04 \%$ & 29 & $25.89 \%$ & 8 & $7.14 \%$ & 3.00 \\
\hline 6 & $\begin{array}{l}\text { Building effective } \\
\text { relationships }\end{array}$ & 4 & $3.57 \%$ & 48 & $42.86 \%$ & 22 & $19.64 \%$ & 28 & $25.00 \%$ & 10 & $8.93 \%$ & 2.93 \\
\hline 7 & Decision making & 2 & $1.79 \%$ & 19 & $16.96 \%$ & 14 & $12.50 \%$ & 33 & $29.46 \%$ & 44 & $39.29 \%$ & 3.88 \\
\hline 8 & Planning skills & 5 & $4.46 \%$ & 3 & $2.68 \%$ & 23 & $20.54 \%$ & 47 & $41.96 \%$ & 34 & $30.36 \%$ & 3.91 \\
\hline 9 & Sharing leadership & 6 & $5.36 \%$ & 23 & $20.54 \%$ & 44 & $39.29 \%$ & 27 & $24.11 \%$ & 12 & $10.71 \%$ & 3.14 \\
\hline 10 & Motivational skills & 1 & $0.89 \%$ & 3 & $2.68 \%$ & 32 & $28.57 \%$ & 37 & $33.04 \%$ & 39 & $34.82 \%$ & 3.98 \\
\hline 11 & Knowledge & 5 & $4.46 \%$ & 5 & $4.46 \%$ & 19 & $16.96 \%$ & 42 & $37.50 \%$ & 41 & $36.61 \%$ & 3.97 \\
\hline 12 & Problem solving & 3 & $2.68 \%$ & 23 & $20.53 \%$ & 35 & $31.25 \%$ & 32 & $28.57 \%$ & 19 & $16.96 \%$ & 3.36 \\
\hline 13 & Negotiation & 4 & $3.57 \%$ & 20 & $17.86 \%$ & 38 & $33.93 \%$ & 24 & $21.43 \%$ & 26 & $23.21 \%$ & 3.43 \\
\hline 14 & Confidence & 6 & $5.36 \%$ & 15 & $13.39 \%$ & 28 & $25.00 \%$ & 31 & $27.68 \%$ & 32 & $28.57 \%$ & 3.61 \\
\hline 15 & Setting objectives & 3 & $2.68 \%$ & 38 & $33.93 \%$ & 26 & $23.21 \%$ & 27 & $24.11 \%$ & 18 & $16.07 \%$ & 3.17 \\
\hline 16 & Prioritization & 8 & $7.14 \%$ & 37 & $33.04 \%$ & 36 & $32.14 \%$ & 25 & $22.32 \%$ & 6 & $5.36 \%$ & 2.86 \\
\hline 17 & Strategic planning & 3 & $2.68 \%$ & 17 & $15.18 \%$ & 34 & $30.36 \%$ & 22 & $19.64 \%$ & 36 & $32.14 \%$ & 3.63 \\
\hline 18 & Networking skills & 6 & $5.36 \%$ & 13 & $11.61 \%$ & 24 & $21.43 \%$ & 38 & $33.93 \%$ & 31 & $27.68 \%$ & 3.67 \\
\hline 19 & Team work & 5 & $4.46 \%$ & 14 & $12.50 \%$ & 21 & $18.75 \%$ & 32 & $28.57 \%$ & 40 & $35.71 \%$ & 3.79 \\
\hline 20 & Building bonds & 13 & $11.61 \%$ & 22 & $19.64 \%$ & 35 & $31.25 \%$ & 28 & $25.00 \%$ & 14 & $12.50 \%$ & 3.07 \\
\hline
\end{tabular}

\subsubsection{Employees Perception of Leadership}

The last section of the questionnaire asked participants whether where agree or do not agree with 12 statements. Participants had to rank the statements using a 5 point scale which comprised form do not agree at all, do not agree, not sure, agree and totally agree. Figure (17) and Table (7) show that participants agreed the most with statements 3,8 and 10; which reflects the situation within their organizations. The following sections will review each statement to see how respondents felt in regards to the statement. 


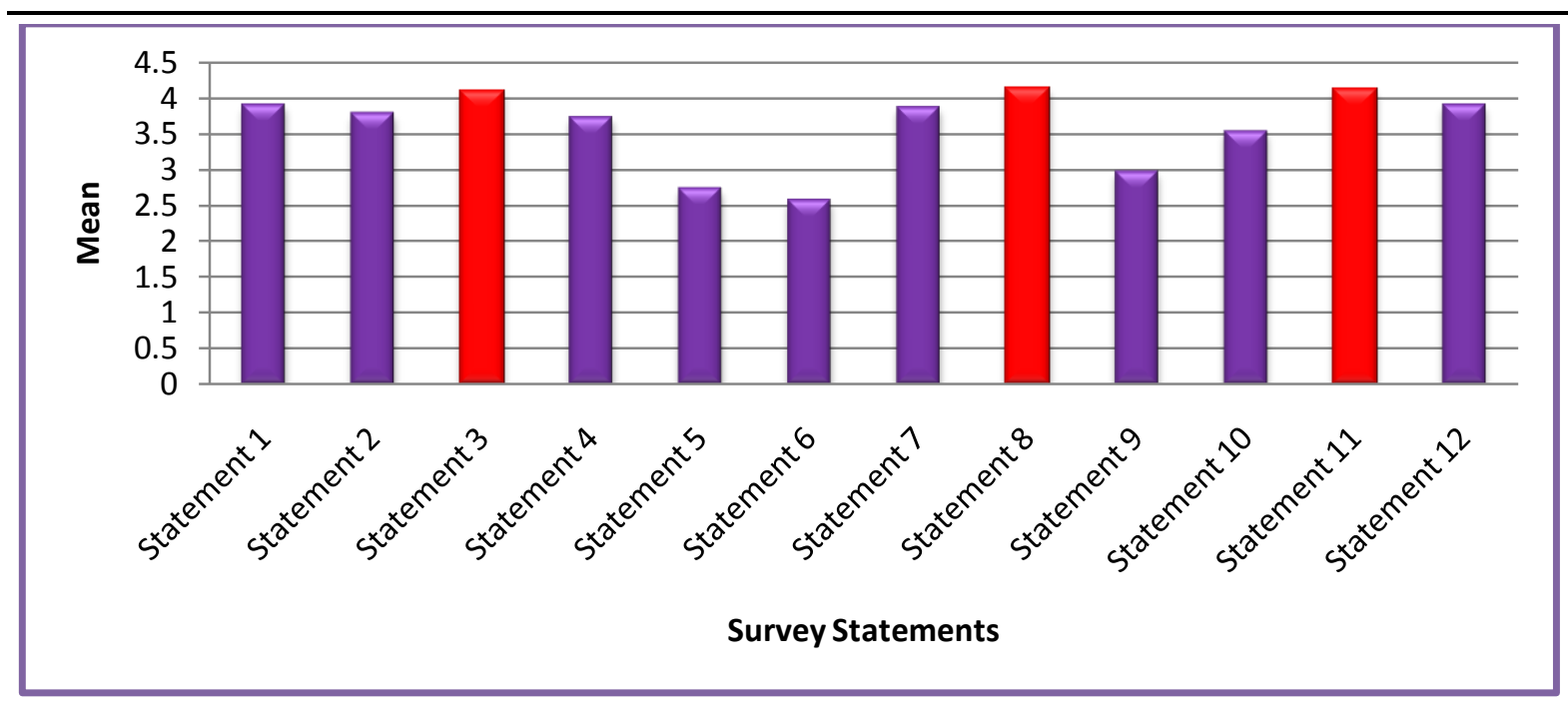

Figure17. Results of Employees Perception of Leadership

Statement 1: You fully trust top management in your organisation.

$41 \%$ of employee's agreed with this statement which shows mutual trust within the organisational culture. However, $20 \%$ of employee's from both organisations disagreed with the statement. Figure 18 depicts the responses using a pie chart and table 7 lists all the statements See Figure (18).

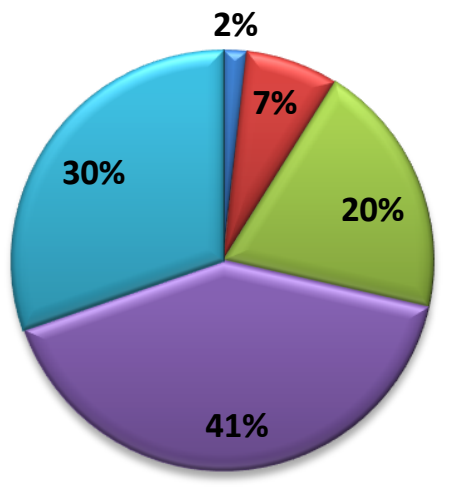

Not sure

$\square$ Totally dis agree

$\square$ Disagree

$\square$ Agree

$\square$ Totally agree

Figure18. Response Rate to Statement 1

Table7. Results of Employees Perception of Leadership

\begin{tabular}{|c|c|c|c|c|c|c|c|c|c|c|c|c|}
\hline \multirow[t]{2}{*}{ SQ. } & \multirow[t]{2}{*}{ Statement } & \multicolumn{2}{|c|}{ Not Sure = 1} & \multicolumn{2}{|c|}{$\begin{array}{ll}\text { Totally } & \text { Dis } \\
\text { agree }=2 & \end{array}$} & \multicolumn{2}{|c|}{ Dis agree $=3$} & \multicolumn{2}{|c|}{ Agree $=4$} & \multicolumn{2}{|c|}{$\begin{array}{ll}\text { Totally } & \text { agree } \\
=5 & \\
\end{array}$} & \multirow[t]{2}{*}{ Mean } \\
\hline & & $F$ & $\%$ & $F$ & $\%$ & $F$ & $\%$ & $F$ & $\%$ & $F$ & $\%$ & \\
\hline 1 & $\begin{array}{l}\text { You fully trust top } \\
\text { management in your } \\
\text { organisation. }\end{array}$ & 2 & $1.79 \%$ & 8 & $7.14 \%$ & 22 & $19.64 \%$ & 46 & $41.07 \%$ & 34 & $30.36 \%$ & 3.91 \\
\hline 2 & $\begin{array}{l}\text { Your manager knows how to } \\
\text { delegate and when to } \\
\text { delegate. }\end{array}$ & 15 & $13.39 \%$ & 0 & $0.00 \%$ & 25 & $22.32 \%$ & 36 & $32.14 \%$ & 31 & $27.67 \%$ & 3.47 \\
\hline 3 & $\begin{array}{l}\text { Conflicts are usually } \\
\text { managed by the manager in } \\
\text { your organisation. }\end{array}$ & 0 & $0.00 \%$ & 1 & $0.89 \%$ & 23 & $20.54 \%$ & 52 & $46.43 \%$ & 36 & $32.14 \%$ & 4.10 \\
\hline 4 & $\begin{array}{l}\text { Top management in your } \\
\text { organisation are } \\
\text { approachable. }\end{array}$ & 3 & $2.68 \%$ & 12 & $10.71 \%$ & 19 & $16.96 \%$ & 55 & $49.10 \%$ & 23 & $20.54 \%$ & 3.74 \\
\hline 5 & $\begin{array}{l}\text { There is possibility to occupy } \\
\text { leadership position in your } \\
\text { organisation. }\end{array}$ & 20 & $17.86 \%$ & 18 & $16.07 \%$ & 48 & $42.86 \%$ & 23 & $20.54 \%$ & 3 & $2.68 \%$ & 2.74 \\
\hline 6 & $\begin{array}{l}\text { You received training on } \\
\text { leadership when you started } \\
\text { in your organisation. }\end{array}$ & 25 & $22.32 \%$ & 27 & $24.11 \%$ & 37 & $33.04 \%$ & 16 & $14.29 \%$ & 7 & $6.25 \%$ & 2.58 \\
\hline 7 & $\begin{array}{l}\text { You receive continuous } \\
\text { feedback from your manager. }\end{array}$ & 3 & $2.68 \%$ & 8 & $7.14 \%$ & 23 & $20.54 \%$ & 43 & $38.39 \%$ & 35 & $31.25 \%$ & 3.88 \\
\hline
\end{tabular}


The Impact of Managers' Leadership Skills on Construction Project Performance in Dubai

\begin{tabular}{|l|l|l|l|l|l|l|l|l|l|l|l|l|l|}
\hline 8 & $\begin{array}{l}\text { The feedback you receive } \\
\text { from your manager has } \\
\text { enhanced your leadership } \\
\text { perception. }\end{array}$ & 2 & $\mathbf{1 . 7 9 \%}$ & 2 & $\mathbf{1 . 7 9 \%}$ & 6 & $\mathbf{5 . 3 6 \%}$ & 69 & $\mathbf{6 1 . 6 1 \%}$ & 33 & $\mathbf{2 9 . 4 6 \%}$ & $\mathbf{4 . 1 5}$ \\
\hline $\begin{array}{l}\text { The relationship between you } \\
\text { and your manager depends } \\
\text { more on first impression. }\end{array}$ & 7 & $\mathbf{6 . 2 5 \%}$ & 29 & $\mathbf{2 5 . 8 9 \%}$ & 44 & $\mathbf{3 9 . 2 9 \%}$ & 23 & $\mathbf{2 0 . 5 4 \%}$ & 9 & $\mathbf{8 . 0 4 \%}$ & $\mathbf{2 . 9 8}$ \\
\hline $\begin{array}{l}\text { When you face problems } \\
\text { personal or technical), the } \\
\text { first person you ask for help } \\
\text { is your manager. }\end{array}$ & 5 & $\mathbf{4 . 4 6 \%}$ & 17 & $\mathbf{1 5 . 1 8 \%}$ & 21 & $\mathbf{1 8 . 7 5 \%}$ & 51 & $\mathbf{4 5 . 5 4 \%}$ & 18 & $\mathbf{1 6 . 0 7 \%}$ & $\mathbf{3 . 5 4}$ \\
\hline 11 & $\begin{array}{l}\text { The managers in your } \\
\text { organisation has the required } \\
\text { leadership skills to lead the } \\
\text { organisation. }\end{array}$ \\
\hline $\begin{array}{l}\text { You are treated according to } \\
\text { your skills and capabilities. }\end{array}$ & 10 & $\mathbf{8 . 9 2 \%}$ & 0 & $\mathbf{0 . 0 \%}$ & 4 & $\mathbf{3 . 5 7 \%}$ & 73 & $\mathbf{6 5 . 1 7 \%}$ & 25 & $\mathbf{2 2 . 3 2 \%}$ & $\mathbf{3 . 9 1}$ \\
\hline
\end{tabular}

Statement 2: Your manager knows how to delegate and when to delegate.

This statement caused some confusion amongst employees as $14 \%$ said they were not sure about this statement, however, the majority of participants agreed with this statement with $64 \%$ of respondents either totally agreeing or agreeing with the statement. See Figure (19).

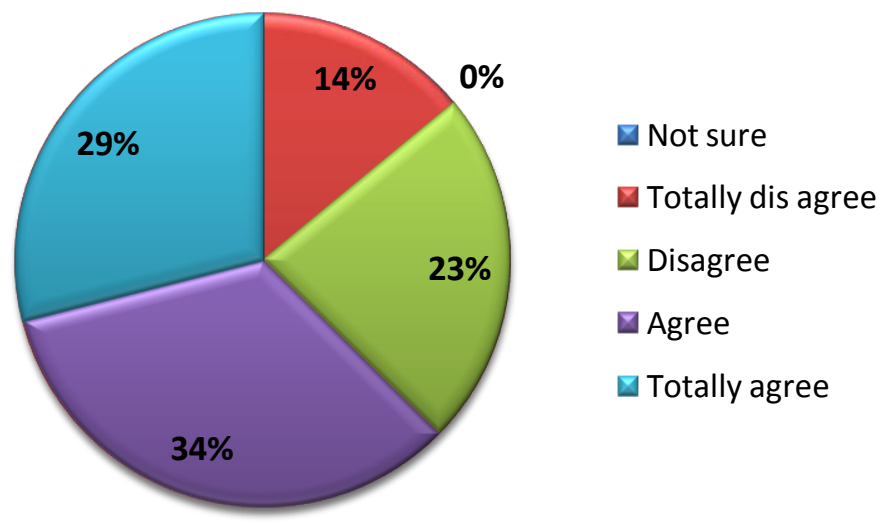

Figure19: Response Rate to Statement 2

Statement 3: Conflicts are usually managed by managers in your organisation.

This statement was one amongst the top three statements as over $78 \%$ of participants either agreed or totally agreed with this statement. This shows that one of the main roles of the project manager for both organisations is to manage conflicts. Moreover, the high response for 'totally agree' shows that this is a key role for managers. See Figure (20).

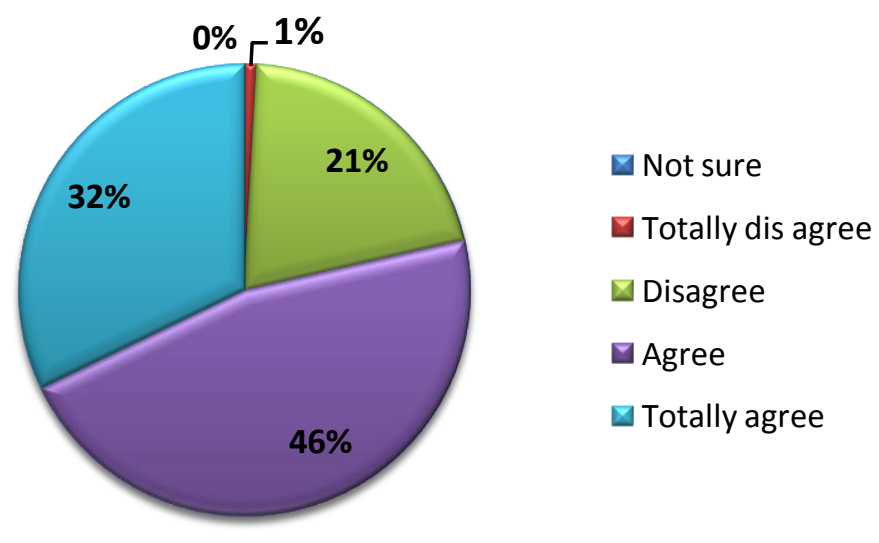

Figure20. Response Rate to Statement 3 
Statement 4: Top management in your organisation are approachable.

This statement divided respondents; some agreed whilst some disagreed; this may be due to the position and job description for each employee. Whilst, the majority of employees agreed with the statement as $70 \%$ of employees chose either 'agree' or 'totally agree.' This reflects the style of leadership in these two organisations and the degree of satisfaction of employees who find their managers approachable and easy going. See Figure (21).

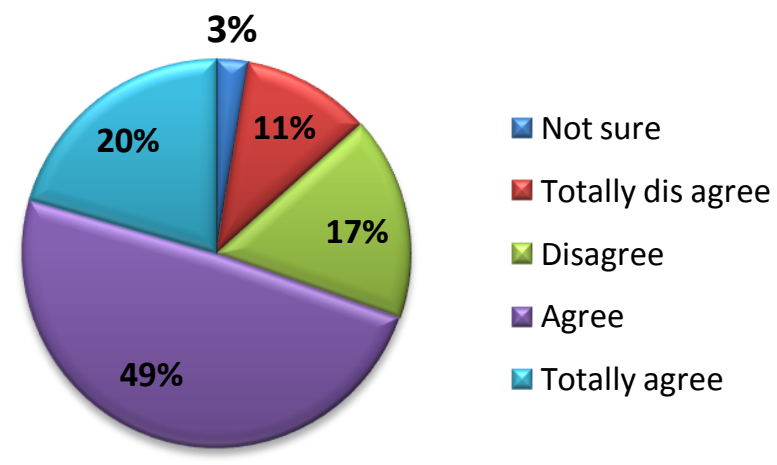

Figure21. Response Rate to Statement 4

Statement 5: There is possibility to occupy leadership positions within your organisation.

$43 \%$ of respondents answered with "disagree" and 16\% with "Totally Disagree", proving that in the employees view leadership positions in their organisations is unapproachable and reserved for specific people who have the capability to occupy these positions. See Figure (22)

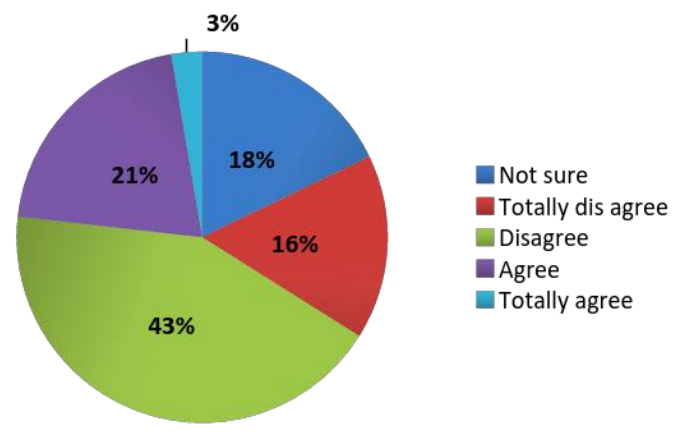

Figure22. Response Rate to Statement 5

Statement 6: You received training on leadership when you started in the organisation.

The majority of respondents answered "Disagree" and "Not Sure" for this statement, which reflects the situation of the construction industry in Dubai as employees feel far away from leadership principles. 33\% of respondents answered "Disagree" demonstrating their awareness of leadership requirements but they lack the required preparation which is essential to rise in the hierarchy. See Figure (23).

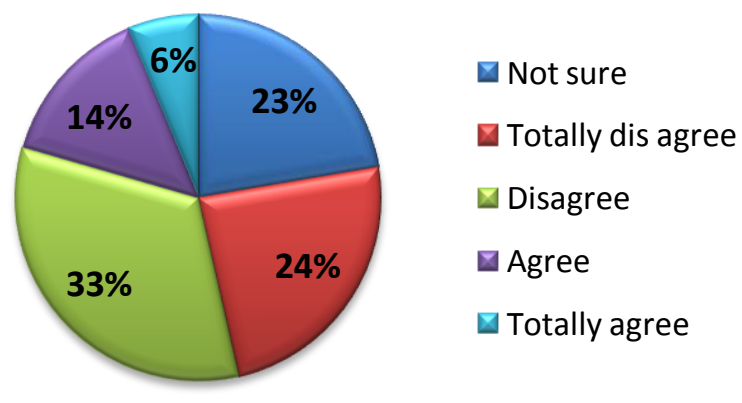

Figure23. Response Rate to Statement 6 
Statement 7: You receive continuous feedback from your manager.

This statement has reflected the positive side of management within the two organisations, as almost $70 \%$ answered "Agree" and "Totally agree". This verifies that employees are receiving continuous feedback from their managers. These results also identified key leadership skills (which were mentioned above in section three of the survey) that relate to controlling group performance and building effective relations. See Figure (24).

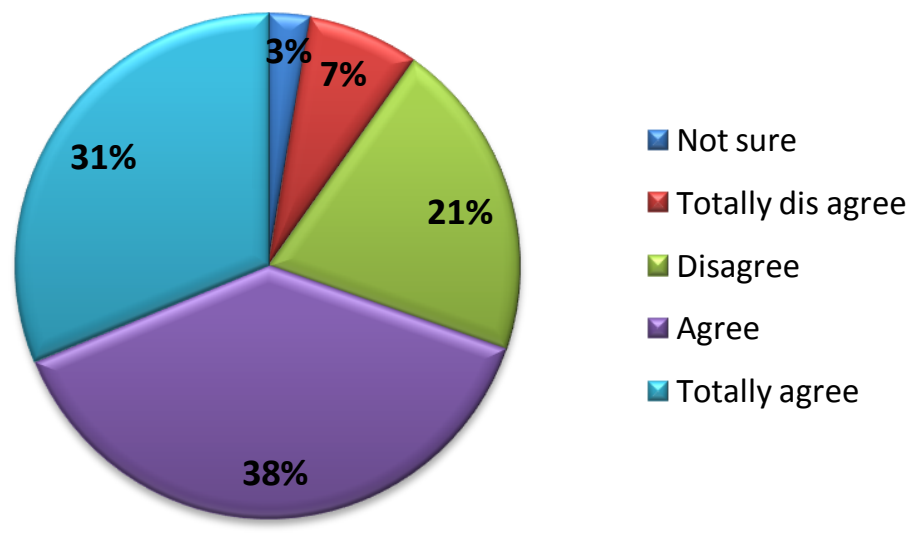

Figure24. Response Rate to Statement 7

Statement 8: The feedback you received from your manager has enhanced your leadership perception.

This statement was ranked as the most agreed statement amongst the other twelve statements with (4.15) in the mean analysis. Moreover, 62\% of respondents "Agree" with the statement and 29\% "Totally agree" forming almost $91 \%$ of the respondents. The degree of acceptance for this statement demonstrates that an essential element within a leader is related to continuous feedback, shared leadership with followers, and the follower's reflection to the manager's concerns. See Figure (25).

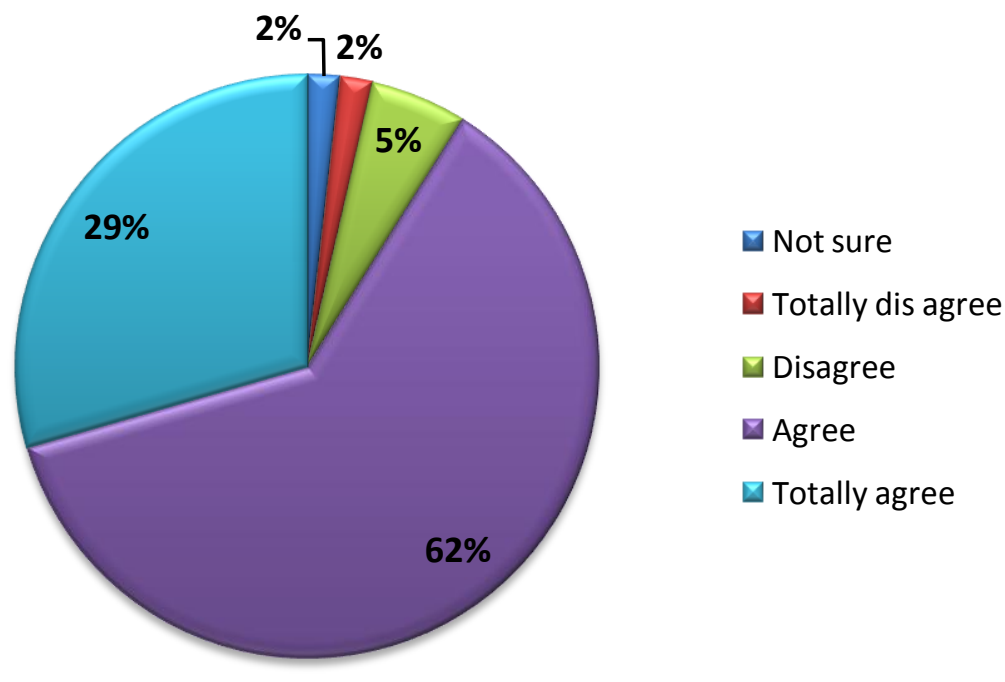

Figure25. Response Rate to Statement 8

Statement 9: The relationship between you and your manager depends more on first impressions.

Once again, the answers were very varied and there was a mix between "Agree" and "Disagree", however, the majority (almost 65\%) disagreed with this statement. This shows that managers treat employees differently, and this relates to the manager's leadership skills of monitoring and communication. See Figure (26). 


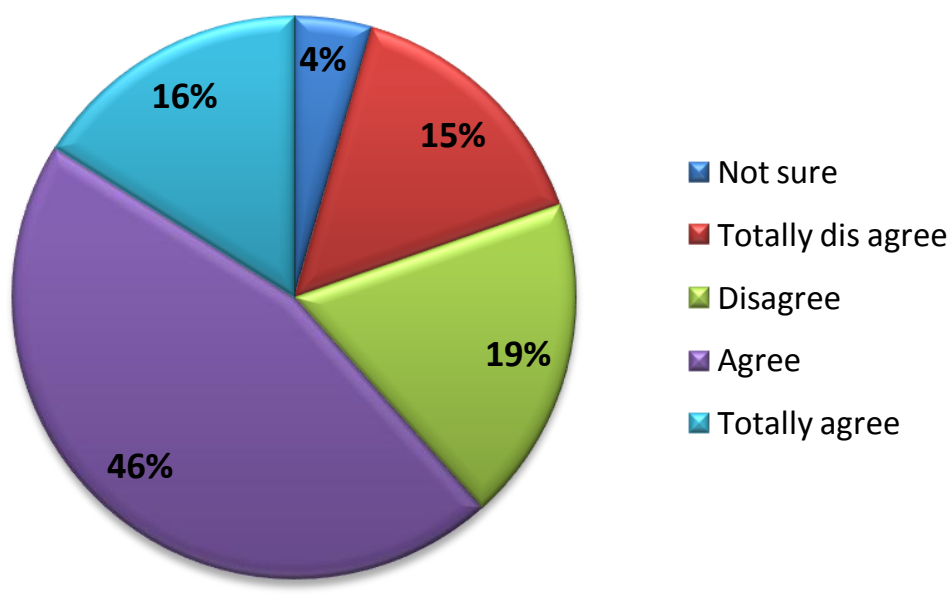

Figure26. Response Rate to Statement 9

Statement 10: When you face problems (personal or technical), the first person you ask for help from is your manager.

The reason behind putting this statement in the survey was to evaluate the degree of collaboration between managers and employees. $46 \%$ of respondents agreed; identifying another leadership skill "building effective relations". Also, these answers were not collected from managers, as the results would be biased, meaning they would not reflect the actual situation between team members and themselves. See Figure (27).

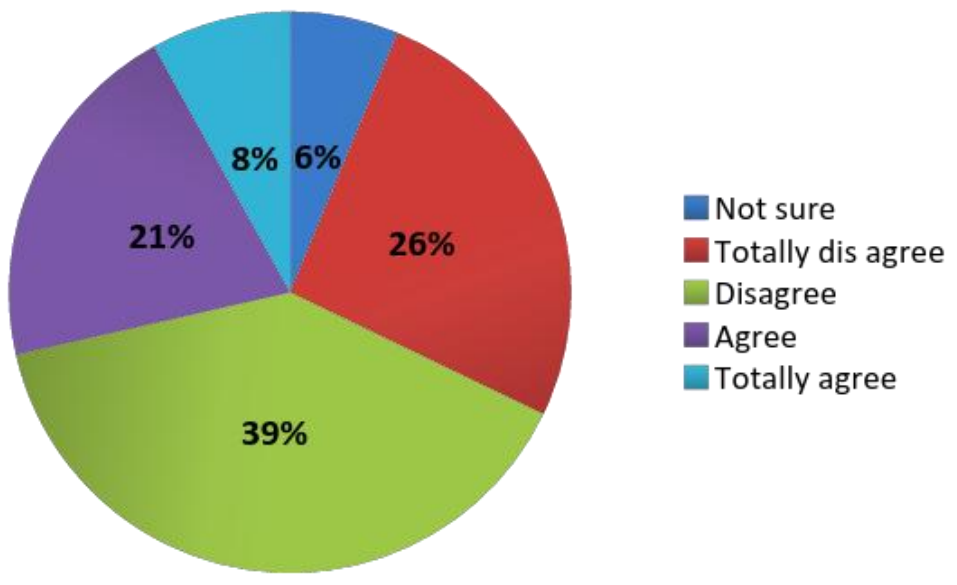

Figure27. Response Rate to Statement 10

Statement 11: The managers in your organisation have the required leadership skills to lead the organisation.

This statement was ranked as the second most agreed statement, with a mean analysis of 4.13 , which is high in comparison to other statements. In order to analyse the response to this statement correctly, in-depth investigation is required for each of the respondent's leadership backgrounds and perceptions. This issue was further discussed with managers in the interviews, where managers clarified the required leadership skills required. However, the general impression obtained from this statement shows that employees are satisfied with the ability of their managers. See Figure (28). 


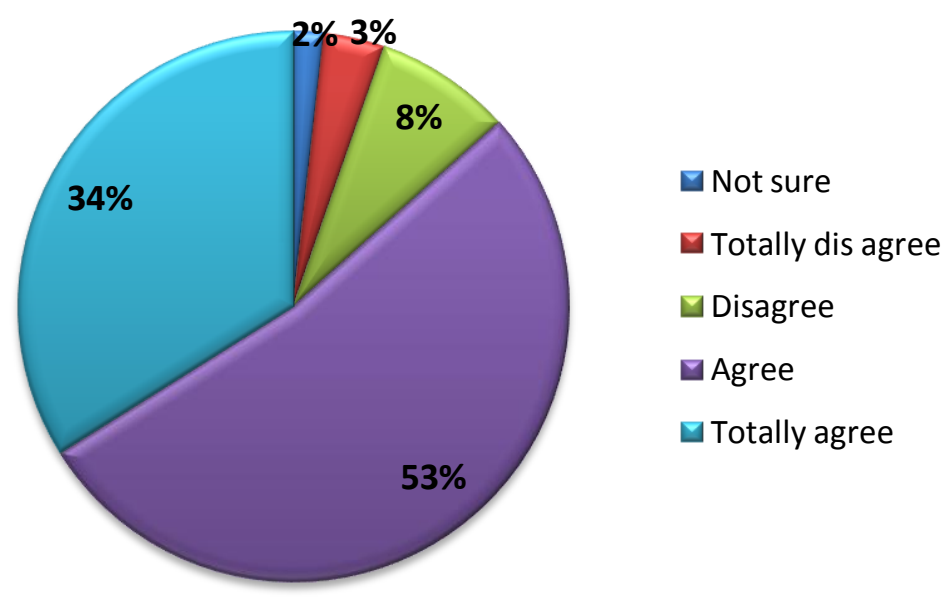

Figure28. Response Rate to Statement 11

ST.12: You are treated according to your skills and capabilities.

The last statement concerned the employees' opinion on whether they are satisfied with their job. Almost $87 \%$ of respondents agreed with the statement which shows the professional attitude of the employees at these two organisations and the positive culture inside the team. See Figure (29).

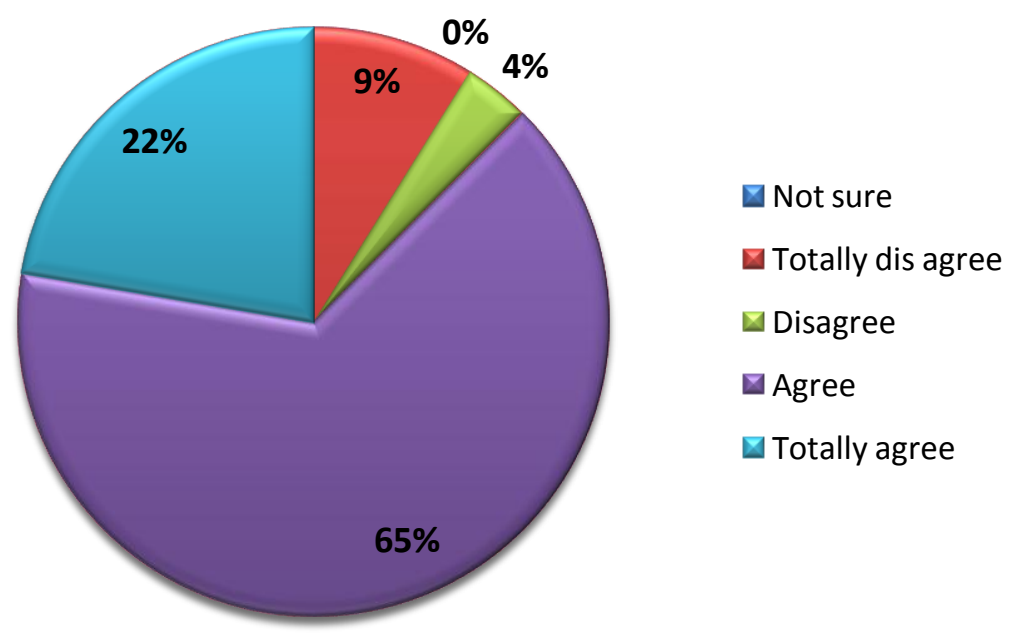

Figure29. Response Rate to Statement 12

\section{Conclusion}

In this chapter, research outcomes will be expressed briefly based on the research findings obtained from the literature review and data analysis.

The aim of the research was to investigate the leadership skills of project managers and its impact on the performance of construction projects in Dubai. From the literature, a lack of research was identified regarding leadership skills of project managers and people working within the construction industry. Most previous research focused on leadership styles and attributes with little concern given to skills. Therefore, the motive behind this research was based on previous experience for the researcher within Dubai's construction industry and to establish a potential for further research in the future about leadership skills. The research strategy for this study was to conduct a literature review on the project management process, project manager roles and compare management and leadership and provide a successful definition of a successful project based on previous research. Next, the leadership aspect was reviewed in detail starting from definitions of leadership and leaders to then focusing on leadership theories and models in depth to demonstrate the knowledge gap relating to 
leadership skills. Three leadership models were found to be constructive and reinforced the research problem; the theories in these models were used later on in the data collection process. Consequently, the research approaches and strategies used to collect and analyse the data aimed to fill the knowledge gap regarding leadership skills within Dubai's construction industry. Moreover, the data received was valuable and addressed the problem.

The most effective leadership skills according to people working within Dubai construction industry is explained in detail in chapter four above. It was found that a good leader must have good communication skills and social skills; they should be attached to people outside of working hours as workers performance is based on the quality of treatment they receive from their managers. Additionally, if a leader lacks technical skills it could be recovered by having effective leadership skills supported by continuous improvement. Moreover, for any leader that seeks to be effective within Dubai's construction environment must be aware of two aspects; firstly the culture of the construction industry overall and how to deal with it. This comes with experience and studying the culture from a leaders' perspective. Secondly, a leader must be aware of the organisational culture and deal with employees as effective team members by appreciating their actions as a leader and being a team member at the same time.

Moreover, Dubai's construction industry is experiencing a huge development in the quality and quantity of projects, however, most projects managers are concerned about the task rather than focusing on their own leadership skills. At the same time, the employees showed some satisfaction about their job and the type of treatment they received from their managers.

In conclusion, an effective leader could be described as a person who is followed by people and not a person who orders people. In other words, leadership is a concept more than a job title and could be attached to any member that influences and changes peoples' life and the organisation. This change cannot be achieved without leaders equipped with the required leadership skills that differentiate them from normal managers. Also, leadership skills is still quite a new topic that needs to be researched further but senior project managers in Dubai expressed a positive impression about the construction industry in the future due to the growing interestin leadership skills. Therefore, this research could be utilized to establish a new perspective for further research and encourage future researchers to think outside the box and seek continuous improvement to investigate project managers' leadership skills.

\section{REFERENCES}

Adair, J. (2013). Develope Your Leadership Skills (1st ed.). London, Hampshier, ngland : Kogan Page Limited .

Agyekum-Mensah, G. (2012). Adaption of structured analysis design techniques methodology for construction project planning. Edinburgh: Association of Researchers in Construction Management.

Barker, R. (1997). How can we train leaders if we do not know what leadership is? New York: Human Relations.

Bass, R. (2008). The Bass hand Book of Leadership, Theory, Research and managerial Applications. New Yourk: Free Press.

Black, R., \& Mouton , J. (1964). The Managerial Grid. Houston: Gulf.

Brinkmann, S. (2013). Qualitative Interviewing: Understanding Qualitative research. Oxford: OXFORD University Press.

CIOB. (2002). Code of Practice for Project Management for Construction and Development (Third ed.). Oxford: Blackwell.

Creswell , J., \& Plano clark, V. (2011). Designing and Conducting Mixed Methods research. London: SAGE Publications.

Creswell, J. (2014). Research design Quatattive, Qualetative and mixed Methods Approaches (4th ed.). london: SAGE Publications.

Daft, R. (2008). The Leadership experiance (Fourth ed.). Mason,USA: Thomson Higher Eduction.

Drucker, P. (1999). Managing Oneself. New York: Harvard Business Review.

Dulaimi, M., \& Langford, D. (1999). Job Behavior of Construction Project Managers Determinants and Assessment. Journal of Construction Engineering and Management, 256-264. 
Egan , S. (1998). Rethinking Construction. London: Crown Copyright.

Easterby-Smith, M., Richard, T., \& Paul, J. (2012). Management Research. London: SAGE Publications Ltd.

Eliot, S. (2010). Ten Distinctions "Between"Quantitative" and "Qualitative" Studies. An"article"by"Susan"Eliot, 1-2.

Fairchild , A. (2003). INSTRUMENT RELIABILITY AND VALIDITY :Introductory Concepts and Measures. James Madison University.

Fairholm , M. R. (2004). Different prespectives on the practice of leadership ,Public Administration review.

French, R. (2007). Cross-cultural management in work organisations. London: Chartered institute of personnel and development.

French, R., Rayner, C., Rees, G., \& Rumbles, S. (2011). Organizational Behaviour (2 ed.). Chichester: John Wiley \& Sons.

Gharehbagh, K., \& Kerry , M. (2003). The Construction Manager as a Leader." Leadership and Management in Engineering.

Gregory, R. (1992). Psychological testing: history, principles and applications. Boston: Allyn and Baco.

Griffin, R., \& Moorhead, G. (2010). Organizational Behaviour: Managing people and Organizations (Ninth ed.). Mason, USA: Macmillan Publishing solutions.

Grint , K. (2005). the social construction of leadership.

Jackson, T. (1995). Cross-cultural management. Oxford: Butterworth-Heinemann.

Kerzner, H. (2009). A Systems Approach to Planning, Scheduling, and Controlling (Tenth edition ed.). New York: John Wiley \& Sons, Inc.

Kotter, J. (2001). What leaders really do? Harvard Business Review.

Kubicek, J. (2011). Leadership is Dead: How Influence is Reviving it. New York: Howard.

Kumar, R. (2014). Research methodology: A step-by-step guide for beginners (4th ed.). Los Angeles: SAGE.

Kvale, S. (2007). Doing interviewes. london: SAGE Publications.

Kvale, S. (1996). InterViews: An Introduction to Qualitative Research Interviewing. London : SAGE Publications Ltd.

Lencioni, P. (2002). The Five Dysfunctions of a ,Team A Leadership Fable. San Francisco: JosseyBass, A Wiley Imprint.

Maxwell, J. C. (2006). 360 Leader: Developing your influance from anywhere in the Organisation. USA: Maxwell motivation and JAMAX Realty .

Meind, 1., \& Ehrlick, S. (1987). The Romance of leadership and the evaluation of organizational performance. Academy of Management Journal.

Mintzberg , H. (2009). Henry Mintzberg Managing . San Franscico: Perrett-Loehler .

Muijs, D. (2011). Doing Quantitative Research in Education with SPSS (2nd ed.). London: SAGE Publications Ltd.

Mumford, M., \& strange, J. (2002). Charismatic versus ideological leadership.

Munshi, N., Stafylarakis, M., Oke, A., Puranam, P., Towells, S., Moslein, K., et al. (2005). Leading for innovation. London: Advanced Institute of Management and Research.

Nahavandi, A. (2003). The Art and Science of Leadership. Upper Saddle River, New Jersey:: Prentice Hall.

Newstrom, J., \& Pierce, J. (2010). Leaders and the Leadership Process (6th ed.). New York: McGraw Hill.

Odusami, K. T. (2000). Perceptions of Construction Professionals Concening. Journal of Management in Engineering.

Parahoo, K. (1997). Nursing research: principles, process and issues. Basingstoke: Macmillan.

Park, S. (2009). . Whole Life Performance Assessment: Critical Success Factors. Journal of Construction Engineering \& Management, 1146-1161. 
PMBOK. (2008). AGide of Project Management Body of Knowledge (Fourth ed.). USA: Project Management institute.

Rollinson, D. (2002). Organisational Behaviour and Analysis. London : Prentice Hall.

Rudestam , K., \& Newton , R. (2015). surviving Your Dissertation (4th ed.). USA: SAGE Publications.

Sadler-Smith, E. (2006). Learning and Development for Managers. London: Black Well .

Saunders , M., Lewis , P., \& Thornhill, A. (2009). Research methods for business Students (5th ed.). Essex ,Engliend: Pearson Eduavrion limited.

Skipper, C., \& Bell, L. (2006). Influences Impacting Leadership Development. Journal of Management in Engineering, 68-74. 